\title{
Russian Ecological Education: History of Formation and Development (the End of XX- the Beginning of XXI Century)
}

\author{
Olga Otrokova \\ Bauman Moscow State Technical University \\ 5/1, 2nd Baumanskaya Street \\ Moscow, Russia 105005 \\ E-mail: otrokova@yandex.ru \\ Valery Remarchuk \\ Bauman Moscow State Technical University \\ 5/1, 2nd Baumanskaya Street \\ Moscow, Russia 105005 \\ E-mail: dekan.fsgn@bmstu.ru
}

\author{
Vladimir Inozemtsev \\ Bauman Moscow State Technical University \\ 5/1, 2nd Baumanskaya Street \\ Moscow, Russia 105005 \\ E-mail: inozem_63@mail.ru \\ Olga Shcherbakova \\ Bauman Moscow State Technical University \\ 5/1, 2nd Baumanskaya Street \\ Moscow, Russia 105005 \\ E-mail: infobox900@mail.ru
}

\begin{abstract}
The article analyzes the history of environmental education formation and development in the Russian Federation in the XX- early XXI centuries. The forms and role of ecological education, transforming its system, aimed at forming students' meta-subject skills and abilities. The authors come to the conclusion that currently the ecological culture of the population is in the process of formation, that reflects the trends of the environmental education evolution in modern Russia in order to achieve the most important strategic goal sustainable development of the country.
\end{abstract}

Keywords - concept of sustainable development; meta-subject skills; the Russian Federation (RF); ecological culture; ecological education

\section{INTRODUCTION}

The modern stage of development is one of the most difficult in the mankind history. In the XXI century a large majority of people understands that the world is facing an ecological disaster, being aware of the devastating effect of any delay in solving this problem [1, p. 96].

Most researchers believe that the time has come to create a new type of environmental culture that can involve both ethnic traditions and customs, as well as modern scientific and technological achievements. And what is the most important, it will allow «interaction of society and nature in accordance with the ecological and moral imperatives" [2, p. 218]

The basis of all changes is to understand the obvious. "A human is a part of nature." This awareness cannot be achieved without the establishing, developing and functioning of environmental education that should become a public matter in most countries. Only by forming a system of continuous environmental education the sustainable development of society can be ensured [3, p. 52-53]

In 1956, the UNESCO, at one of its meeting for the first time raised the question of education in connection with the necessity to understand the environmental problems. Since then, in the developed countries of Europe, public policy has been aimed at the forming environmental education and its functioning. We have already a significant positive experience. The Federal Republic of Germany, which began to deal with environmental problems in the 1960s, is outstanding on the general background. It is the country that began to pursue a consistent environmental policy. Currently, the Germans unanimously approve this approach, considering to be the result of joint efforts of the state and citizens and are ready to continue protecting the environment This means, above all, the successful educational and training activities in Germany [4, pp. 151-153]. Significant progress in this sphere has also been made by Norway, Holland, Denmark [5, p. 111-112].

It should be noted that in Russia we also began considering the need to address these issues in the $\mathrm{XX}$ century. In our country the great scientist V. I. Vernadsky not only developed his noosphere doctrine, demanded in the world scientific community, but tried to put the nature protection on a practical basis, proposing to organize in 1915 the Commission for the Study of the Natural Productive Forces of Russia (COPS), uniting the best scientific minds of the country in it. However, these ideas were not in demand for a long time either by Russian society or the state.

Then ecological education began to emerge in the Soviet school system. In the 1970s and 1980s new global trends affected the Soviet Union, but much was reduced to declarativeness [6, c.3-5] The collapse of the USSR in 1991 
accentuated the environmental problems in each of the former Soviet republics. It is time to realize the necessity to solve them in modern Russia.

In our country, the reformation of the educational policy in the field of environmental education has begun.

\section{ECOLOGICAL EDUCATION SYSTEM IN MODERN RUSSIA}

The starting point of the changes was the law of the Russian Federation "On Environmental Protection" (1991). In this document the necessity to form the universal, integrated and continuing environmental education and preschool, school and out-of-school education was declared. Responsibility for its implementation was placed on to the executive authorities - from the Government of the Russian Federation to local authorities. Then in 1992 another important legal document was adopted, namely the law "On Education". "Teaching love to the environment" has become one of the national policy principles. In December 1993, the Constitution of the Russian Federation was adopted. There were two interrelated articles. Article 42 guaranteed the right of everyone "to favorable environment, reliable information on its state and the right to compensation of the damage caused to health or property by environmental offenses". Article 58 stated: Everyone is obliged to preserve nature and the environment, to take care of natural resources"[7]. Thus, the Supreme normative legal act of the Russian Federation formed the legal basis for the system of universal continuous environmental education and education in the country.

Conceptual ideas and theoretical approaches to organizing continuous ecological education system were defined in the works by S. V. Alekseev, A. A. Verbitsky, N. F. Vinokurov, G. N. Canopf, N. N. Moiseev [8, p. 4].

At the joint session of the Board of the Ministry of education of Russia and the Ministry of natural resources of Russia (1994), devoted to the issue "On the environmental education of students in general education institutions of the Russian Federation", for the first time the national security function related to the environmentally protected sustainable development of Russia was assigned to the environmental education. All these activities contributed to the fact that in 1994 "Ecology" was introduced in secondary educational institutions as an independent school subject.

Simultaneously, positive changes were taking place in the vocational education system. On the initiative of the State Committee for environmental protection, the source of financing environmental education - the funds of environmental funds of all levels, was determined.

However, another important problem had not been solved. At the Federal level there was not enough time to develop ecology educational programs, to prepare textbooks and teaching aids. However, the way out was found. In each region, everything for providing the educational process began to be developed and produced, financed by environmental funds.
A new mechanism for the environmental education democratization was created. It was allowed to allocate up to $10 \%$ of funds coming to environmental funds of different levels to the environmental education development. According to the Ministry of natural resources of Russia, in 2002 the system of additional environmental education involved already $38 \%$ of schoolchildren.

At the same time, work was underway in order to create an educational standard as a Federal regulation norm, formed in the new conditions of single educational space. A new draft educational standard on ecology for the basic curriculum had been developed by 1998. The normative legal base adopted in the 1990s became the basis for the forming a system of continuous environmental education and a reference point for the transition to new principles of sustainable development of the country $[9$, p. 15].

Since the beginning of the XXI century in the school system the subject "Ecology" was referred to the subjects of the regional component of the education content. This fact significantly limited its distribution in the subjects of the Russian Federation. In these circumstances, the educational practice was based on different models of environmental education: mono-subject, multi-subject and combined. The first model is connected with introducing the subject "Ecology" in the school curriculum, the second — with including environmental issues in the subjects (ecological education). The least spread third model focused on the strengthening the environmental component in all academic disciplines on a wide interdisciplinary basis and introducing a separate integrated environmental course in the curricular, extracurricular and after-school activities [10, p. 3-7].

At the same time, there were positive changes in the daily teaching activities. Culture has become a benchmark for the developing environmental education, its defining role is associated with the national territorial traditions. Specialized institutions were established in a number of constituent entities of the Russian Federation. For example, environmental colleges (Stavropol), high schools (Voronezh, Volgograd). Lyceums (Barnaul, Yekaterinburg, Chelyabinsk and Moscow) were opened. There were profiled schools (Belgorod, Yekaterinburg, St. Petersburg and Chelyabinsk). Specialized classes in educational institutions (Kaluga, Moscow, Perm and Tambov regions) were arranged. The development of this direction was also facilitated by the emerging Russian Federation regulatory legal framework of the subjects in the field of environmental education and culture. 12 regions of the country introduced laws on environmental education. Among them there were the Republics of Dagestan and Bashkortostan, Sakha (Yakutia), Primorsky and Kamchatka regions. As well as the region Ulyanovsk, Ivanovo, Kostroma, Volgograd, Tyumen, Irkutsk and Khanty-Mansiysk. 60 regions of the Russian Federation have adopted regulations defining the principles and objectives of environmental education and upbringing of children and young people.

Public organizations had a great influence on forming environmental culture and education, their activities intensified in the last five years. It is important to note that 
the centers of environmental education for children are museums, zoos, botanical gardens, libraries, children art houses, summer camps [11, C.].224]. These institutions held festivals, exhibitions of children drawings, competitions and other interesting activities [12, p.160-162]. Thus, the allRussian society for nature protection every two years organizes all-Russian conferences for preschool children, annual contests for the best work performance on children environmental education in preschool educational institutions. Since 2009, the project of international organization of pre-school education for children up to 8 years in the field of education for sustainable development has been implemented. About 250 pre-school and other educational institutions, as well as individual families (in Moscow, Volgograd, Kazan, Izhevsk, Togliatti and other cities) have participated in the project. With adopting the concept of Russian education modernization, the focus on the environmentally oriented human activity management. This fact determined the introduction of requirements for forming «environmental competence", a new approach to forming independent use of meta-subject skills in different socio-problem areas.

In general, this trend is compliant with international decisions on sustainable development. Forming education for sustainable development (ESD) takes place on the basis of the UN regulatory documents. Its formation was initiated by the UN in Rio de Janeiro at the conference on environment and development (UNCED, 1992).

In 2002, the UN resolution proclaimed the Decade of education for sustainable development (DESD - 2005-2014) in Johannesburg, UNESCO has been designated as the leading agency [13]. This confirmed the need for close cooperation between countries in the field of education [14]. Then, the specification of the DESD activities continued in e preparing the Strategy of the European Economic Commission (UNECE Strategy) (Vilnius, 2005), the preliminary results were summed up at the UNESCO world conference (Nagoya, Japan, 2014) [15].

The concept of sustainable development is a socioeconomic orientation to the progressive movement of the world community in the context of the overall globalization process. From the pedagogical point of view, the main meaning of education is making all levels of education ecological. This, in turn, will ensure the formation of the environmental culture of citizens and achieve the main goal - sustainable development, both of their countries and the world as a whole [16, C.43-44].

We are emphasizing the qualitatively new model of education for sustainable development (based on a holistic approach to a person, society and nature, on the unity of modern scientific knowledge and humanistic values and philosophical attitudes). In this model, the developing system of ecological education and ecological culture should be based on a variety of extracurricular activities: project and research and practical environmental activities. Parents, teachers, scientists, representatives of the public and business should be actively involved in such work. These conditions contributed to the development of forms of network interaction in formal and non-formal education [17, C.283284].

In Russia, environmental education in implementing the Federal State Educational Standard (FSES) of General Education is carried out at all levels of education, as provided in the Federal law of December 29, 2012 № 273FZ "On Education in the Russian Federation"[18]. At the present time, environmental education in our country actually starts in pre-school institutions. In a number of preschool education programmes, subsections related to environmental education and children development ("the World of Discovery", "From Birth to School", "Origins") can be highlighted. As there are some restrictions as far as possible contacts of preschool children with wildlife are concerned, we can note the emerging unique environmental projects in the system of pre-school education (resource saving, smart city, ecological trace, etc.). Every year, the system of preschool educational organizations arranges environmental holidays, creates "environmental passports" of kindergartens, the movement of "Green kindergartens" is being formed $[19$, C. 22-24].

In the school system, the process of creating more ecological education is carried out within the framework of academic subjects, from the basics of environmental literacy (primary general education: grades 1-4) to mastering students ' environmental thinking (basic general education: grades 5-9) and environmental culture of behavior in the surrounding world (secondary general education: grades 1011). Training involves forming the younger generation rules of behavior in the world of nature and people, understanding the relationship between natural, social, economic and political phenomena, awareness of their impact on the quality of human life and the quality of the environment. However, only in high school (the standard of secondary complete general education) provides the opportunity to study the environment as an independent subject (basic level)-the subject of choice. This fact is rather a barrier to forming ecological views of children and youth [20, C.8283].

The all-Russian Olympiad in ecology (5-11 classes) contributes to improving the status of environmental education and culture. Every year (since 1994), about 300 thousand schoolchildren from almost all subjects of the Russian Federation participate in this event. In the system of additional education, the environmental component in forming the behavioral culture is implemented through programs of additional education of ecological and biological orientation, including mass environmental events (including environmental expeditions, trips, actions, etc.). If in 2015 in the system of children additional education there were 219 organizations of ecological and biological orientation (206.6 thousand children were engaged), by 2017 their number increased by $10 \%$, and the number of children and youth covered by this direction increased 1.5 times. Among the most popular environmental events of federal importance are: all-Russian ecological festival of children and youth, all-Russia competition of young environment researchers, all-Russian competition "My Small Motherland: Nature, Culture, Ethnicity", all-Russian junior forest 
competition "Unnat", all-Russian contest "Yunnat", allRussian meeting of young ecologists, all-Russian meeting of school forests, all-Russian specialized ecological shift for winners and prize-winners of the Olympics [21, C.169]. All these competitions have a common goal to form the younger generation's environmentally responsible worldview and to increase the level of natural science literacy.

Russian higher education also tries to take into account the approaches developed by UNESCO [22]. Ecologically oriented programs of higher vocational education were introduced in Russian universities almost everywhere, the maximum number is in Moscow, Saint-Petersburg [23, c. 20206]. FSES of higher education sets the task of forming students ' special competences in the field of ecology, as well as in the field of environmental protection in the specialties and training areas, included in the enlarged groups of training areas and specialties: from "Agriculture, Forestry and Fishing" to "Air Navigation and Operating Aviation and Rocket-Space Technology" [24, C.85].

269 universities provide training in the field of ecology and environmental protection, most of them under the Ministry of education and science of Russia (69.9\% of the total amount of students in these areas of training) and the Ministry of Agriculture of Russia (17.8\% of students). Ministry of education and science, takes into account the needs of the Russian economy in highly qualified staff, with the participation of key employers of constituent entities of the Russian Federation and the responsible centers (Ministry of education and science, Ministry of Agriculture of Russia, Federal Forestry Agency, the Emergency Ministry of Russia and the Association of Classical Universities of Russia).

\section{CONCLUSION}

Thus, the formation of the environmental education system passed several stages in its development: from the nature education to environmental education, and then to the transition period of forming environmental culture. In the process of the environmental education development of the country, the goals, objectives, content and methodological tools of education have been transformed. Despite the awareness of the importance of the environmental education system reforms in pursuit of sustainable development, pedagogical traditions (based on the acquired knowledge assimilation, the reproduction of real connections and relations) should be focused on the readiness of the younger generation to the uncertainties of the future[25]. In particular, the climate preservation issues are being actively developed by Russian science, are taken into account in the state plans, but are poorly presented in education (in schools).

In 2015, Russia signed the Paris Agreement within the UN Framework Convention on Climate Change. Russia agreed with the UN General Assembly Resolution 70/1 of September 25, 2015 "transforming the world (Agenda for sustainable development for the period till 2030"). Undoubtedly, the transition of Russian education to the path of "global sustainability" took place. At the same time, it should be recognized that Russian environmental education has a number of serious omissions, lagging behind the western one [26]. This is due primarily to the fact that the ecologization of education abroad began much earlier, in sufficiently developed countries, whose intellectual elite realized all the risks associated with disregard for nature.

In general, the analysis of domestic environmental education has shown that the process of forming ecological culture has started in the country. The basis for teaching is integrated content, meta-subjectivity, application of new educational technologies [27, c.133-134]. Of course, there is still a lot of routine work, connected with preparing programs at all levels, creating state standards, developing both disciplinary and interdisciplinary principles of pedagogical activity. Undoubtedly, the strategy proposed by the UN must be adapted to domestic realities.

In modern conditions, environmental education is an integrating factor that determines the strategic goal and the leading directions of global sustainable development. The goal of the entire education process is the personality with high ecological culture, understood, in the final analysis, as a culture of attitude to nature, to the society and to oneself [28, c.51]. At the same time, education for sustainable development should ensure that everyone can participate in improving the quality of his or her own life, the life of the community around him or her and of all mankind.

\section{REFERENCES}

[1] Sennitskaya L. V. The Importance of environmental knowledge in the educational process // Culture and education: scientific and information magazine of the universities of culture and arts. 2016. №3 (22) Pp. 91-97.

[2] Krivosheeva E. S., Eisner L. Y. Axiological component of the environmental culture // Bulletin of Krasnoyarsk State Agrarian University. 2012. No. 4. Pp. 217-221.

[3] Rozenberg G. S. and Khasaev G. R., Gelashvili D. B., Saksonov S. V., Shlyakhtin G. V. Two axioms of survival in the modern world: ussustained development and environmental education // Samarskaya Luka: problems of regional and global ecology. 2017. Vol. 26. No. 2. Pp. 48-72.

[4] Dushkova D. O., Kirillov S. N. Ecologization of consciousness as one of the basic principles of environmental policy // Bulletin of the Volgograd State University. Series 3: Economy. Ecology. 2017. Vol. 19.No. 2. Pp. 148-158. Pushkova D. O., Kirillov S. N. Ecological consciousness as one of the main principles of environmental policy// Bulletin of the Volgograd state University. Series 3: Economy. Ecology. 2017. Vol. 19.No. 2. Pp. 148-158.

[5] Pugachev A.V. Environmental policy in some European countries: different approaches // Bulletin of the Kemerovo State University, 2014.Vol.1. No. 3 (59) Pp. 109-112.

[6] Tolmacheva V. V. Development of social and ecological knowledge in Russia in the XX century // Scientific and methodical electronic journal "Concept". 2017. No. S10. Pp. 45-49.

[7] "The Constitution of the Russian Federation " of 12.12 .1993 ( with the amendments made by Laws of the Russian Federation on amendments to the Constitution of the Russian Federation of 30.12.2008 N 6 - FKZ, of 30.12.2008 N 7-FKZ, of 05.02.2014 N 2FKZ, of 21.07.2014 N 11 - FKZ) // Consultant Plus. [Electronic resource.]

http://www.consultant.ru/document/cons_doc_LAW_28399/ (date accessed 21.06.2018).

[8] Astrakhantseva I. V. Educating ecologically oriented personality of students of pedagogical institution of higher education as active carriers of ecological culture. // Thesis for the degree of candidate of pedagogical Sciences: 13.00.08- Theory and methodology of 
professional education. - Ulyanovsk State Pedagogical University named after I. N. Ulyanov". - Ulyanovsk, 2017. - 294 pages.

[9] Chuikova L. Y. Analysis of the development of environmental education in the Russian Federation // Astrakhan Bulletin of ecological education. 2011. No. 1 (17). Pp. 7-19.

[10] Morozova N. B. Theoretico-methodological and methodotechnological aspects of forming ecological culture of future specialists // Scientific and methodical electronic journal" Concept". 2012. No. 4. Pp. 8-17.

[11] Gvozdkova I. A., Frolova N. V., Koskina A. O. Actual problems of developing perspective directions of ecological education and upbringing // Bulletin of the University (State University of Management). 2014. Pp. 224-227.

[12] Sofronov R. P., Tovarishcheva F. D. Education of ecological culture of students in the conditions of summer ecological camp // Scientific notes, electronic scientific journal of Kursk state University.2014 №4 (32). Pp. 158-164.

[13] Final document of the UN Conference on sustainable development "the Future we want" [Electronic resource]. URL: http://www.un.org/ru/sustainablefuture (date accessed 19.06.2018).

[14] Education for sustainable development. UN decade of education for sustainable development (2005-2014) [Electronic resource]. URL: http:// www.unesco.org (date accessed 07.06.2018).

[15] Draft international plan of action for the United Nations Decade of education for sustainable development [Electronic resource]. URL: http undocu1nesco.orgimages 0013001390 139023r.pdf (date accessed 09.12.2018)

[16] Panov V. I., Lidskaya E. V. The concept of sustainable development: ecological thinking, consciousness, responsibility // Herald of the M. A. Sholokhov Moscow State University for the Humanities, SMSUH named after M. A. Sholokhov. 2012. No. 1. Pp. 38-50.

[17] Ryabov S. S., Eudin T. A., Khlebosolova G. V. Value attitude to nature as a component of environmental culture //Structuralfunctional organization and dynamics of vegetation cover. Materials of 2nd all-Russian scientific and practical conference with international participation, dedicated to the 80th birth anniversary of the D. B. S., prof. V. I. Matveeva. Collection of works of the conference. Samara: Publisher: University, 2015. Pp. 280-285.

[18] Federal law "On education in the Russian Federation" of 29.12.2012 N 273-FZ (last edition) // Consultant Plus. [Electronic resource.] URL: http://www.consultant.ru/document/cons_doc_LAW_140174/(date accessed 10.06.2018).

[19] Zykova O. A. Do you need an environmental specialist in the kindergarten? // Modern pre-school education. Theory and practice. 2010. No. 2. P. 22-25

[20] Makarova, O. V., Nikolaeva O. V. Ecological thinking and ecological culture in the Russian education// Tsarskoye Selo readings. 2010. Vol.1.No. 14. Pp. 81-85.

[21] Yanbaev Y. A., Urazova O. I., Talysheva I. Z., Shayakhmetova I. Z., Gilmutdinova R. A. Education for sustainable development as the basis for forming an environmental worldview // Health and education in XXI century. 2017. Vol. 19. No. 1. Pp. 168-170.

[22] The World Declaration on Higher Education for the Twenty-first Century: approaches and practical measures. [Electronic resource.] URL: http://www.conventions.ru/view_base.php?id=1496

[23] Salakhov R. F., Salakhova R. I., Gaptraupova Z. N. Ecological culture of students: problems of formation // Philological Sciences. Theory and practice. 2017. No. 7(73): in 3 vol. Vol. 2 Pp. 204-207.

[24] Titova A.V., Naumov G. B., Ecology and education // Mining industry. 2017. No. 3. Pp. 82-86.

[25] State report "On the state and protection of the environment of the Russian Federation in 2014" // the Ministry of natural resources and environment of the Russian Federation. [Electronic resource]. URL: http://www.mnr.gov.ru/regulatory/detail.php?ID=142679 (date: 10.06.2018).

[26] Ursul A. D., Ursul T. A. Education for sustainable development: first results, problems and prospects // Socio-dynamics. 2015. No. 1. Pp. 11-74. DOI: 10.7256/2409-7144.2015.1.14001. URL: http://enotabene.ru/pr/article_14001.html (date accessed 25.06.2018).
[27] Abdurakhmanov G. M., Guseinov N. O., Ivanchenko Yu. Yu., Prokopchick S. V., Kadieva D. I., Soltanmuradova Z. I. Education in the interests of us-sustained development as the basis of formation of ecological worldview// South of Russia: ecology, development. 2017. Vol. 12. No. 3. P. 115-137. DOI: 10.18470/1992-1098-2017-3-115$137 /$

[28] Doroshko O. M. Modern approaches to the definition of "ECOLOGICAL CULTURE" //Modern researches of social problems (Electronic scientific journal). 2012. No. 9 (17). P. 51 